ORIGINAL ARTICLE / ARTIGO ORIGINAL

\title{
Socioeconomic status and cardiovascular
} risk factors in young adults: a cross-sectional analysis of a Brazilian birth cohort

\author{
Situação socioeconômica e fatores de risco cardiovascular em jovens: \\ uma análise transversal de uma coorte de nascimentos brasileira
}

\author{
Fernando Alberto Costa Cardoso da Silva' (D), Maylla Luanna Barbosa Martins Bragançal (D), \\ Heloisa Bettiol" (D), Viviane Cunha Cardoso" (D), Marco Antonio Barbieril" (D), \\ Antônio Augusto Moura da Silva' (iD
}

\begin{abstract}
Introduction: In high-income countries, persons of high socioeconomic status (SES) have a lower cardiovascular risk. However, in middle and low-income countries, the results are controversial. Objective: To evaluate the association between family income and cardiovascular risk factors in young adults. Methods: A total of 2,063 individuals of a birth cohort initiated in 1978/79 in the city of Ribeirão Preto, Brazil, were evaluated at age of 23/25 years. Cardiovascular risk factors (hypertension, sedentary lifestyle, smoking, low highdensity lipoprotein (HDL)-cholesterol, high low-density lipoprotein (LDL)-cholesterol, high fibrinogen, insulin resistance, diabetes, abdominal and total obesity, and metabolic syndrome) were evaluated according to family income. Income was assessed in multiples of the minimum wage. Simple Poisson regression models were used to estimate the prevalence ratios (PR) with robust estimation of the variance. Results: High-income women showed lower prevalences of low HDL-cholesterol $(\mathrm{PR}=0.47)$, total obesity ( $P R=0.22)$, abdominal obesity $(P R=0.28)$, high blood pressure $(P R=0.28)$, insulin resistance $(P R=0.57)$, sedentary lifestyle $(P R=0.47)$, metabolic syndrome $(P R=0.24)$, and high caloric intake $(P R=0.71)(p<0.05)$. High-income men showed lower prevalences of low HDL-cholesterol $(P R=0.73)$ and sedentarism $(P R=0.81)(p<0.05)$. These results may be explained by the fact that high-income women pay more attention to healthy habits and those with the lowest family income are least likely to access health services resources and treatments. Conclusion: Women were in the final phase of the epidemiologic transition, whereas men were in the middle phase.
\end{abstract}

Keywords: Risk factors. Cardiovascular diseases. Young adult. Income.

'Postgraduation Program of Collective Health, Department of Public Health, Universidade Federal do Maranhão - São Luís (MA), Brazil. "Department of Puericulture and Pediatrics, Faculty of Medicine of Ribeirão Preto, Universidade de São Paulo - Ribeirão Preto (SP), Brazil.

Corresponding author: Augusto Moura da Silva. Rua Barão de Itapari, 155, Centro, CEP 65020-070, São Luís, MA, Brazil. E-mail: aamouradasilva@gmail.com

Conflict of interests: nothing to declare - Financial support: Fundação de Amparo à Pesquisa do Estado de São Paulo, protocol number 2000/09508-7. 
RESUMO: Introdução: Em países de alta renda, indivíduos de situação socioeconômica elevada apresentam menor risco cardiovascular. Em países de média e baixa rendas, os resultados são controversos. Objetivo: Avaliar a associação entre renda familiar e fatores de risco cardiovascular em adultos jovens. Metodologia: Estudo seccional em que foram avaliados 2.063 indivíduos aos 23/25 anos de uma coorte de nascimento iniciada em 1978/79 na cidade de Ribeirão Preto, Brasil. Avaliaram-se fatores de risco cardiovascular (hipertensão arterial, sedentarismo, tabagismo, HDL - colesterol baixo, LDL - colesterol elevado, fibrinogênio alto, resistência insulínica, diabetes, obesidade abdominal e total e síndrome metabólica) de acordo com renda familiar. A renda foi avaliada em múltiplos do salário mínimo. As razões de prevalências (RP) foram estimadas em modelos de regressão de Poisson simples, com estimativa robusta da variância. Resultados: Mulheres de maior renda apresentaram menores prevalências de HDL - colesterol baixo $(R P=0,47)$, obesidade total $(R P=0,22)$ e abdominal $(R P=0,28)$, resistência insulínica $(R P=0,57)$, pressão arterial elevada $(R P=0,28)$, sedentarismo $(R P=0,47)$, síndrome metabólica $(R P=0,24)$ e alta ingestão calórica $(R P=0,71)(p<0,05)$. Os homens de maior renda apresentaram menores prevalências de HDL - colesterol baixo $(R P=0,73)$ e sedentarismo $(R P=0,81)(p<0,05)$. Pode ser que mulheres de alta renda prestem mais atenção aos hábitos saudáveis e aquelas com menor renda têm menor probabilidade de acessar recursos e tratamentos de serviços de saúde. Conclusão: As mulheres encontravam-se na fase final da transição epidemiológica, enquanto os homens, na fase intermediária.

Palavras-chave: Fatores de risco. Doenças cardiovasculares. Adulto jovem. Renda.

\section{INTRODUCTION}

Cardiovascular diseases currently represent a serious public health problem worldwide, being the main cause of morbidity and premature mortality. By 2025, more than $80 \%$ of all cases of cardiovascular diseases and diabetes are expected to occur in middle and low-income countries ${ }^{1}$. Cardiovascular risk factors (CRF) are conditions associated with early onset cardiovascular disease. Some of these risks are not amenable to change, such as sex, age and heredity; others may be changed, such as smoking, hypertension, dyslipidemia, obesity, diabetes mellitus / carbohydrate intolerance, sedentarism, psychosocial stress and some factors related to hemostasis, inflammation and thrombosis, recently considered to be $\mathrm{CRF}^{2}$.

Socioeconomic status (SES) is defined as the position a person occupies in the society to which he/she belongs, measured according to income, occupation and/or education. Some studies have demonstrated an association between SES and $\mathrm{CRF}^{3,4}$. Researches conducted in high-income countries have demonstrated that high-income persons have a lower cardiovascular risk, whereas low-income ones present a higher cardiovascular risk. These differences in cardiovascular risk factors between the wealthy and the poor are attributed to the epidemiologic transition ${ }^{4 \cdot 6}$.

The epidemiologic transition that started in the past century in high-income countries seems to be characterized, in its initial phase, by a worse cardiovascular risk in the high-income groups of the population. In its intermediate phase, this difference seems to disappear 
due to a worsening of cardiovascular risk in poorer persons, while wealthier persons would continue to have an unchanged and unfavorable cardiovascular risk. In the final phase of this transition, there seems to be an inversion in the relation between income and cardiovascular risk that would lead to a lower cardiovascular risk in the wealthier population and a higher one in the poorer population ${ }^{7,8}$.

Studies conducted in middle-income countries, in addition to being scarce, have reported controversial results. One research demonstrated a higher cardiovascular risk among high-income persons ${ }^{9}$, while another concluded that the cardiovascular risk was lower among wealthier people ${ }^{10}$. It is still unknown whether the inversion of the association between SES and CRF observed in high-income countries has already occurred in middle-income countries ${ }^{11}$.

The objective of the present study was to determine whether high-income persons have a lower cardiovascular risk than low-income ones from a birth cohort re-assessed at 23 to 25 years of age in Ribeirão Preto, Brazil. The question was: had the epidemiologic transition been concluded or was it still in its intermediate phase in the city of Ribeirão Preto, in 2002-04?

\section{METHODS}

\section{STUDY DESIGN}

The present investigation was a cross-sectional study based on data from a birth cohort started in Ribeirão Preto, Brazil, in 1978/79. This cohort is entitled "Perinatal Health in Ribeirão Preto, São Paulo, Brazil”, and included liveborn singletons delivered at hospitals by mothers residing in the municipality, from June $1^{\text {st }}, 1978$ to May $31^{\text {st }}, 1979$. The persons who participated in the first phase of the research were evaluated at other times, i.e., at school age when they were 8 to 11 years old, at the time of the military draft, and at the age of 23 to 25 years. This study used data collected at young adult age from April 2, 2002 to May 12, 2004.

\section{SAMPLE}

A total of 9,067 mothers of liveborns were first interviewed in 1978/79, representing 98\% of the total number of liveborns in Ribeirão Preto during the study period. Children whose mothers did not reside in the city $(2,094)$ and twins (146) were excluded. Thus, 6,827 liveborns were included in the first phase. A new evaluation was performed from 2002 to 2004 when the subjects were 23 to 25 years old. The following procedures were used to locate the cohort subjects: search of the addresses in the original birth charts, enrollment in schools, 
inscriptions in health plans and in the Unified Health system, military service, and search in the telephone list.

The survey revealed that 343 subjects had died and 819 were not identified, with 5,665 subjects thus having been located. This group was submitted to systematic selection, with the first of each three names being selected according to birth date and geographic region of the city. If the selected subject was not available, the next name down on the list was chosen. 705 subjects were lost to follow-up, due to the following reasons: refusal to participate (209), detention (31), death after 20 years of age (34), or failure to attend the interview (431). The losses were replaced using the same systematic selection, resulting in 2,063 subjects. In addition, 151 young adults were excluded because no information was available about their family income. Thus, the final sample for the present study consisted of 1,912 young adults.

\section{POWER ANALYSIS}

For this study, the power was $86.9 \%$ to detect a $10 \%$ difference in the prevalences between the compared groups for prevalences that were around $50 \%$. The study power was $82.8 \%$ to detect a $5 \%$ difference between the groups for prevalences around $10 \%$, assuming a 0.05 significance level.

\section{STUDY VARIABLES}

The family income of the young adults was determined using a question about this topic during the month preceding data collection. All sources of family income were considered: salaries, investment money, property income, donations by relatives, and any others. The variable family income did not consider the number of family members. The absolute values of this income were calculated as multiples of the Brazilian minimum wage (MW) for each period ( $\mathrm{R} \$ 260.00$ in 2004), and income groups were categorized as less than $5 \mathrm{MW}$, 5 to $9.9 \mathrm{MW}, 10$ to $19.9 \mathrm{MW}$, and $20 \mathrm{MW}$ or more.

The participants were submitted to physical examination and to blood collection performed by a doctor and a trained practical nurse. A $40 \mathrm{~mL}$ blood sample was obtained aseptically from the cubital vein after a fast of at least 12 hours for the determination of fasting glycemia and total cholesterol and fractions. University Hospital, Faculty of Medicine of Ribeirão Preto, Universidade de São Paulo The samples were processed and analyzed in the laboratories of the HCFMRP-USP, by the enzymatic colorimetric method using a Dade Behring Xpand instrument (Dade Behring ${ }^{\circledR}$, Liederbach, Germany) and Dade Behring Dimension (Liederbach, Germany) chemical reagents.Fasting plasma insulin and glucose were used to estimate insulin resistance $($ HOMA 1 - insulin resistance $=$ fasting plasma glycemia $\mathrm{x}$ fasting plasma insulin/22.5, available at http:/ / www.dtu.ox.ac.uk/index.php?maindoc $=/$ homa $/)^{12}$. 
Blood pressure was measured three times ${ }^{13}$ using a digital sphignomanometer adjusted to arm circumference The same evaluator made the measurements at 15 -minute intervals, with the subject sitting and holding his left arm at the height of the heart. The mean value of the last two measurements was considered for analysis.

For the physical examination, the participants wore light clothing and were barefoot. Weight was measured with a mechanical scale (Filizola ${ }^{\circledR}$, Brazil) calibrated before each weighing, with $50 \mathrm{~g}$ precision. Height was measured with a Harpenden model wood stadiometer with $0.1 \mathrm{~cm}$ precision, with the subject standing up.

Body mass index (BMI) was calculated as weight divided by height squared $\left(\mathrm{kg} / \mathrm{m}^{2}\right)$. Waist circumference (WC) was measured with an inextensible metric tape positioned on the smallest circumference between the iliac crest and the last rib. This measurement was performed at the end of a normal expiration, with the subject standing up with a relaxed abdomen.

Total daily caloric intake (in kcal) and percent ingested fat (\%) were calculated with the DietSys software, version 4.0 (National Cancer Institute, Bethesda, MD, USA), based on information obtained with a food frequency questionnaire validated for the Brazilian population ${ }^{14}$. Physical activity was determined using the short version of the International Physical Activity Questionnaire ${ }^{15}$. Smoking habit during the last 30 days was also obtained with a questionnaire.

The following variables were determined: Homeostatic Model Assessment of Insulin Resistance (HOMA IR $-\leq 2.15$, normal or $>2.15$, high $\left.{ }^{16}\right)$, total cholesterol $(<240 \mathrm{mg} / \mathrm{dL}$, normal or $\geq 240 \mathrm{mg} / \mathrm{dL}$, high), low-density lipoprotein (LDL)-cholesterol ( $<160 \mathrm{mg} / \mathrm{dL}$, normal or $\geq 160 \mathrm{mg} / \mathrm{dL}$, high), high-density lipoprotein (HDL)-cholesterol ( $<50 \mathrm{mg} / \mathrm{dL}$, low or $\geq 50 \mathrm{mg} / \mathrm{dL}$, normal for women, $<40 \mathrm{mg} / \mathrm{dL}$, low or $\geq 40 \mathrm{mg} / \mathrm{dL}$, normal for men), triglycerides ( $<150 \mathrm{mg} / \mathrm{dL}$, normal or $\geq 150 \mathrm{mg} / \mathrm{dL}$, high), fibrinogen $(\leq 3.7 \mathrm{mg} / \mathrm{dL}$, normal or $>3,7 \mathrm{mg} / \mathrm{dL}$, high), diabetes (fasting glycemia $>126 \mathrm{mg} / \mathrm{dL}$ or use of a glycemia-lowering drug, or medical diagnosis), high blood pressure (systolic blood pressure $\geq 130 \mathrm{~mm} \mathrm{Hg}$, or diastolic blood pressure $\geq 85 \mathrm{mmHg}$ ), waist circumference (high when $\geq 90 \mathrm{~cm}$ for men or $\geq 85 \mathrm{~cm}$ for women), excessive caloric intake $(>2,900 \mathrm{kcal}$ for men or $>2200 \mathrm{kcal}$ for women $)^{17}$, smoking (no or yes), practicing physical activity (sedentary or non-sedentary), and total obesity when BMI was $\geq 30 \mathrm{~kg} / \mathrm{m}^{2}$.

The criteria of the Joint Interim Statement (JIS) were used to classify the metabolic syndrome $(\mathrm{MS})^{18}$. The JIS considers MS to be present when three or more of the following five factors were detected: abdominal obesity when WC is $\geq 90 \mathrm{~cm}$ for men and $\geq 80 \mathrm{~cm}$ for women, hypertriglyceridemia ( $\geq 150 \mathrm{mg} / \mathrm{dL}$ ), low HDL-cholesterol levels ( $<40 \mathrm{mg} / \mathrm{dL}$ for men and $<50 \mathrm{mg} / \mathrm{dL}$ for women), systemic arterial hypertension (blood pressure $\geq 130 / 85 \mathrm{mmHg}$ or the use of an antihypertensive drug), and high fasting glycemia ( $\geq 100 \mathrm{mg} / \mathrm{dL}$ ).

The Framingham score was applied in order to determine the risk of death due to coronary disease. The Framingham risk equation was computed as the probability of developing a coronary event within 10 years according to sex, based on the following parameters: age, total cholesterol, HDL-cholesterol, smoking, systolic arterial pressure, diastolic 
arterial pressure, and diabetes. The risk of death due to coronary disease is low when less than $10 \%$, moderate from 10 to $20 \%$ and high when more than $20 \%{ }^{19}$. This score was used as a continuous variable.

\section{STATISTICAL ANALYSIS}

The data were weighted because of differential sampling losses at 23 to 25 years. Inverse probability of selection weighting was estimated by logistic regression based on birth weight, parity, preterm birth, marital status, maternal smoking, maternal age, maternal schooling, family income, and maternal occupation. Groups with lower follow-up rates were given greater weights, whereas the ones with higher participation rates were given smaller weights trying to recreate the original composition of the cohort at birth.

The independent variable was family income and the dependent ones were the cardiovascular risk factors. To determine the associations between family income and the cardiovascular risk factors, the $\chi^{2}$ test was applied to the categorical variables and analysis of variance (ANOVA) or the Kruskal-Wallis test was applied to the numerical variables. P value for trend was also calculated for all cardiovascular risk factors.

Simple Poisson regressions with robust estimation of standard errors were performed to determine the association between family income and cardiovascular risk factors, with the level of significance set at 0.05 . No adjustment for confounding was performed, since socioeconomic factors are distal factors in the theoretical model. Because we wanted to estimate the total effect, it would not make sense to adjust for mediators. We also did not adjust for age because the subjects were in a narrow age range (23 to 25 years). All analyses were stratified by sex, giving that a previous study conducted on the same sample had indicated that the associations between family income and adiposity varied between sexes $^{20}$. The STATA ${ }^{\circledR} 14.0$ software (College Station, TX, USA) was used for the analyses.

\section{ETHICAL AND LEGAL ASPECTS}

The study was approved by the Research Ethics committee of HCFMRP-USP (protocol No. 7606/99, on February 7, 2000), and all subjects gave written informed consent to participate.

\section{RESULTS}

When comparing the cardiovascular risk factors according to sex, women showed higher prevalences of diabetes (2.5\%), low HDL-cholesterol (45.1\%), high fibrinogen (15.5\%), high caloric intake $(25.3 \%)$, smoking $(20.9 \%)$, and sedentarism $(54.3 \%)$, whereas men presented 
higher prevalences of high HOMA IR (22.5\%), high triglycerides (16.3\%), high blood pressure $(40.8 \%)$, and metabolic syndrome $(17.8 \%)$. In addition, the Framingham score was higher among men (1.03\%) compared to women (0.53) (Table 1$)$.

The young adult women belonging to the low family income group had higher prevalences of insulin resistance (HOMA IR index - 19.8\%; $\mathrm{p}=0.039)$, low HDL-cholesterol $(52.6 \%$; $<<0.001$ ), total obesity $(14.6 \% ; \mathrm{p}=0.003)$, abdominal obesity $(18.5 \% ; \mathrm{p}<0.001)$, MS $(7.7 \%, \mathrm{p}=0.021)$, and high caloric intake $(27.4 \% ; \mathrm{p}=0.023)$, as well as a higher prevalence of sedentarism $(58.5 \%$; $\mathrm{p}<0.001)$. The median cardiovascular risk measured by the Framingham score was low $(0.46 \%)$, but higher $(0.47 \% ; \mathrm{p}=0.002)$ among low-income women compared to all others (Table 2$)$.

Low-income young adult men had a higher prevalence of low HDL-cholesterol (40.3\%; $\mathrm{p}=0.023)$ and sedentarism $(32.6 \% ; \mathrm{p}=0.044)$ (Table 2). The Framingham score was very low for all groups (median: $0.86 \%$ ) (Table 3 ).

In the Poisson regression models, the young adult women and men belonging to the low-income group were used as reference. High-income women had lower prevalences of insulin resistance (HOMA IR, $\mathrm{PR}=0.57 ; \mathrm{p}=0.009)$, low HDL-cholesterol $(\mathrm{PR}=0.47$;

Table 1. Cardiovascular risk factors according to sex in Ribeirão Preto, 2002-2004.

\begin{tabular}{|c|c|c|c|}
\hline \multirow{2}{*}{ Cardiovascular risk factors } & Men & Women & \multirow{2}{*}{$\mathrm{p}$-value } \\
\hline & $\%(n)$ & $\%(n)$ & \\
\hline High HOMA IR & $22.5(79)$ & $17.6(63)$ & 0.007 \\
\hline Diabetes & $1.3(4)$ & $2.5(4)$ & 0.048 \\
\hline High LDL-cholesterol & $6.1(17)$ & $4.7(18)$ & 0.189 \\
\hline Low HDL-cholesterol & $38.7(128)$ & $45.1(132)$ & 0.005 \\
\hline High total cholesterol & $4.0(11)$ & $4.9(16)$ & 0.286 \\
\hline High triglycerides & $16.3(51)$ & $11.0(41)$ & 0.001 \\
\hline High fibrinogen & $5.2(19)$ & $15.5(15)$ & 0.001 \\
\hline High blood pressure & $40.8(30)$ & $6.3(16)$ & 0.001 \\
\hline Total obesity & $13.2(47)$ & $11.4(43)$ & 0.245 \\
\hline Abdominal obesity & $11.5(40)$ & $14.2(36)$ & 0.090 \\
\hline Metabolic syndrome & $17.8(56)$ & $5.9(50)$ & 0.001 \\
\hline High caloric intake & $18.7(62)$ & $25.3(43)$ & 0.001 \\
\hline High fat consumption & $84.9(260)$ & $86.3(254)$ & 0.460 \\
\hline Smoking & $15.0(63)$ & $20.9(52)$ & 0.001 \\
\hline Sedentarism & $28.9(302)$ & $54.3(76)$ & 0.001 \\
\hline Framingham score* & $1.03(0.69)$ & $0.53(0.34)$ & 0.001 \\
\hline
\end{tabular}

HOMA IR: Homeostatic Model Assessment of Insulin Resistance; LDL: low-density lipoprotein; HDL: high-density lipoprotein; "continuous variable expressed as median and interquartile range. 
$\mathrm{p}<0.001)$, high blood pressure $(\mathrm{PR}=0.28 ; \mathrm{p}=0.011)$, total obesity $(\mathrm{PR}=0.22 ; \mathrm{p}<0.001)$, abdominal obesity $(\mathrm{PR}=0.28 ; \mathrm{p}<0.001 \mathrm{MS}(\mathrm{PR}=0.24 ; \mathrm{p}=0.001)$, high caloric intake $(\mathrm{PR}=0.71 ; \mathrm{p}=0.008)$, and sedentarism $(\mathrm{PR}=0.47 ; \mathrm{p}<0.001)$ (Table 4$)$.

High-income young adult men had lower prevalences of low HDL-cholesterol (PR = .73; $\mathrm{p}=0.026)$ and sedentarism $(\mathrm{PR}=0.81 ; \mathrm{p}=0.029)($ Table 5$)$.

\section{DISCUSSION}

The present study investigated the associations between family income and cardiovascular risk factors among young adults participating in a cohort study in the city of Ribeirão

Table 2. Cardiovascular risk factors according to family income level in minimum wages among women from Ribeirão Preto, in 2002-2004.

\begin{tabular}{|c|c|c|c|c|c|}
\hline \multicolumn{6}{|c|}{ Family income (minimum wages) } \\
\hline \multirow[t]{2}{*}{$\begin{array}{l}\text { Cardiovascular risk } \\
\text { factors }\end{array}$} & $\begin{array}{c}<5 \\
\mathrm{n}=379\end{array}$ & $\begin{array}{c}\geq 5 \text { and } \\
\leq 9.9 \\
n=343\end{array}$ & $\begin{array}{c}>10 \text { and } \leq \\
19.9 \\
n=177\end{array}$ & $\begin{array}{c}\geq 20 \\
\mathrm{n}=79\end{array}$ & \multirow[t]{2}{*}{ p-value } \\
\hline & $\%(n)$ & $\%(n)$ & $\%(n)$ & $\%(n)$ & \\
\hline High HOMA IR & $19.8(81)$ & $16.5(60)$ & $11.6(22)$ & $11.4(9)$ & 0.039 \\
\hline Diabetes & $2.4(9)$ & $1.6(7)$ & $2.7(5)$ & $3.0(2)$ & 0.787 \\
\hline High LDL-cholesterol & $5.8(22)$ & $2.9(9)$ & $4.6(8)$ & $3.2(2)$ & 0.250 \\
\hline Low HDL-cholesterol & $52.6(198)$ & $44.5(151)$ & $30.8(54)$ & $24.7(22)$ & $<0.001$ \\
\hline High total cholesterol & $4.2(16)$ & $3.8(14)$ & $7.2(12)$ & $5.8(4)$ & 0.333 \\
\hline High triglycerides & $10.5(42)$ & $10.7(36)$ & $12.0(22)$ & $16.5(13)$ & 0.499 \\
\hline High fibrinogen & $16.1(63)$ & $16.7(59)$ & $13.9(25)$ & $13.4(11)$ & 0.798 \\
\hline High blood pressure & $7.9(31)$ & $6.1(22)$ & $3.5(7)$ & $2.2(1)$ & 0.086 \\
\hline Total obesity & $14.6(61)$ & $10.6(36)$ & $6.5(12)$ & $3.3(3)$ & 0.003 \\
\hline Abdominal obesity & $18.5(73)$ & $14.2(48)$ & $6.9(13)$ & $5.2(5)$ & $<0.001$ \\
\hline Metabolic syndrome & $7.7(31)$ & $7.1(26)$ & $1.7(4)$ & $1.9(2)$ & 0.021 \\
\hline High caloric intake & $27.4(106)$ & $24.4(80)$ & $16.0(29)$ & $19.7(17)$ & 0.023 \\
\hline High fat consumption & $85.5(326)$ & $87.1(301)$ & $87.9(155)$ & $83.3(66)$ & 0.734 \\
\hline Smoking & $16.3(54)$ & $12.6(40)$ & $12.5(22)$ & $20.2(16)$ & 0.244 \\
\hline Sedentarism & $58.5(222)$ & $54.0(186)$ & $51.8(95)$ & $27.6(23)$ & $<0.001$ \\
\hline Framingham score* & $0.47(0.35)$ & $0.45(0.29)$ & $0.41(0.22)$ & $0.45(0.24)$ & 0.002 \\
\hline
\end{tabular}

HOMA IR: Homeostatic Model Assessment of Insulin Resistance; LDL: low-density lipoprotein; HDL: high-density lipoprotein; "continuous variable expressed as median and interquartile range. 
Preto, São Paulo, Brazil. High-income women showed a lower prevalence of insulin resistance, low HDL-cholesterol, abdominal obesity, total obesity, high blood pressure, metabolic syndrome, high caloric intake, and sedentarism. High-income men presented a lower prevalence of low HDL-cholesterol and sedentarism.

The strong points of the study were the large sample size and the use of various cardiovascular risk factors: blood pressure, lipid profile, obesity, metabolic syndrome, dietary consumption, physical activity, smoking, diabetes, and insulin resistance using the HOMA-IR model, currently accepted for the identification of insulin resistance among young people. In addition, few studies about these aspects are available in low and middle-income countries.

Among the limitations of the study is the fact that, even though this is a birth cohort study, in this analysis, only cross-sectional data were used. Another limitation was the use

Table 3. Cardiovascular risk factors according to family income level in minimum wages among men from Ribeirão Preto, in 2002-2004.

\begin{tabular}{|l|c|c|c|c|c}
\hline \multirow{2}{*}{$\begin{array}{l}\text { Cardiovascular risk } \\
\text { factors }\end{array}$} & $\begin{array}{c}<5 \\
\mathrm{n}=302\end{array}$ & $\begin{array}{c}\geq 5 \text { and } \leq 9.9 \\
\mathrm{n}=288\end{array}$ & $\begin{array}{c}\geq 10 \text { and } \leq \\
19.9 \\
\mathrm{n}=227\end{array}$ & $\begin{array}{c}\geq 20 \\
\mathrm{n}=117\end{array}$ & \multirow{2}{*}{ p-value } \\
\cline { 1 - 5 } & $\%(\mathrm{n})$ & $\%(\mathrm{n})$ & $\%(\mathrm{n})$ & $\%(\mathrm{n})$ & \\
\hline High HOMA IR & $26.2(79)$ & $21.2(63)$ & $20.5(47)$ & $17.1(21)$ & 0.171 \\
\hline Diabetes & $1.1(4)$ & $1.1(4)$ & $1.0(1)$ & $1.5(2)$ & 0.973 \\
\hline High LDL-cholesterol & $4.7(17)$ & $5.6(18)$ & $5.8(14)$ & $10.5(14)$ & 0.129 \\
\hline Low HDL-cholesterol & $40.3(128)$ & $44.4(132)$ & $33.9(75)$ & $29.7(34)$ & 0.023 \\
\hline High total cholesterol & $3.1(11)$ & $4.8(16)$ & $3.0(8)$ & $4.0(5)$ & 0.622 \\
\hline High triglycerides & $15.7(51)$ & $14.1(41)$ & $21.1(48)$ & $12.9(16)$ & 0.143 \\
\hline High fibrinogen & $6.5(19)$ & $5.2(15)$ & $4.5(10)$ & $4.4(6)$ & 0.710 \\
\hline High blood pressure & $10.1(30)$ & $5.5(16)$ & $6.2(14)$ & $4.3(5)$ & 0.233 \\
\hline Total obesity & $15.5(47)$ & $14.9(43)$ & $10.6(24)$ & $8.5(10)$ & 0.123 \\
\hline Abdominal obesity & $13.8(40)$ & $12.4(36)$ & $10.0(23)$ & $8.9(10)$ & 0.448 \\
\hline Metabolic syndrome & $17.9(56)$ & $16.7(50)$ & $17.6(41)$ & $19.8(23)$ & 0.917 \\
\hline High caloric intake & $19.4(62)$ & $16.4(43)$ & $18.0(41)$ & $15.0(15)$ & 0.684 \\
\hline High fat consumption & $82.2(260)$ & $88.1(254)$ & $85.9(199)$ & $88.0(105)$ & 0.290 \\
\hline Smoking & $20.9(63)$ & $18.4(52)$ & $20.0(46)$ & $21.4(25)$ & 0.863 \\
\hline Sedentarism & $32.6(302)$ & $28.0(76)$ & $21.1(50)$ & $26.6(33)$ & 0.044 \\
\hline Framingham score* & $0.87(0.56)$ & $0.83(0.53)$ & $0.85(0.62)$ & $0.93(0.68)$ & 0.375 \\
\hline
\end{tabular}

HOMA IR: Homeostatic Model Assessment of Insulin Resistance; LDL: low-density lipoprotein; HDL: high-density lipoprotein; "continuous variable expressed as median and interquartile range. 
of family income as the only indicator of the socioeconomic status of the subjects, without considering education. However, schooling did not have a discriminatory power since most subjects had a similar educational level ( $84.5 \%$ had more than 12 years of study).

Additional possible limitation could be selection bias, since subjects with a lower income at birth $(25.9 \%)$ had lower participation rates $(\mathrm{p}<0.001)$ in the follow-up than subjects with a higher income at birth (35.4\%). This greater loss of data regarding income among poorer subjects may have prevented the detection of some differences or may have underestimated

Table 4. Association of cardiovascular risk factors with family income level in minimum wages among young adult women from Ribeirão Preto, in 2002-2004.

\begin{tabular}{|c|c|c|c|c|c|}
\hline \multicolumn{6}{|c|}{ Family income (minimum wages) } \\
\hline $\begin{array}{l}\text { Cardiovascular } \\
\text { risk factors }\end{array}$ & $\begin{array}{c}<5 \\
(n=379)\end{array}$ & $\begin{array}{c}\geq 5 \text { and } \leq 9.9 \\
\quad(n=343)\end{array}$ & $\begin{array}{c}\geq 10 \text { and } \leq 19.9 \\
(n=177)\end{array}$ & $\begin{array}{c}\geq 20 \\
(n=79)\end{array}$ & $\begin{array}{l}\mathrm{p} \text { for } \\
\text { trend }\end{array}$ \\
\hline \multicolumn{6}{|c|}{ Prevalence ratio ( $95 \%$ confidence interval) } \\
\hline High HOMA IR & 1.00 & $0.83(0.61-1.14)$ & $0.58(0.37-0.92)$ & $0.57(0.30-1.08)$ & 0.009 \\
\hline Diabetes & 1.00 & $0.67(0.24-1.84)$ & $1.10(0.35-3.40)$ & $1.21(0.32-4.49)$ & 0.842 \\
\hline $\begin{array}{l}\text { High LDL- } \\
\text { cholesterol }\end{array}$ & 1.00 & $0.49(0.23-1.05)$ & $0.80(0.35-1.83)$ & $0.55(0.16-1.85)$ & 0.281 \\
\hline $\begin{array}{l}\text { Low HDL- } \\
\text { cholesterol }\end{array}$ & 1.00 & $0.84(0.72-0.99)$ & $0.58(0.45-0.75)$ & $0.47(0.31-0.69)$ & $<0.001$ \\
\hline $\begin{array}{l}\text { High total } \\
\text { cholesterol }\end{array}$ & 1.00 & $0.90(0.43-1.86)$ & $1.72(0.80-3.66)$ & $1.38(0.50-3.75)$ & 0.224 \\
\hline $\begin{array}{l}\text { High } \\
\text { triglycerides }\end{array}$ & 1.00 & $1.01(0.66-1.57)$ & $1.14(0.69-1.88)$ & $1.56(0.88-2.75)$ & 0.211 \\
\hline High fibrinogen & 1.00 & $1.03(0.73-1.44)$ & $0.86(0.55-1.34)$ & $0.83(0.45-1.49)$ & 0.449 \\
\hline $\begin{array}{l}\text { High blood } \\
\text { pressure }\end{array}$ & 1.00 & $0.77(0.44-1.32)$ & $0.45(0.19-1.01)$ & $0.28(0.06-1.19)$ & 0.011 \\
\hline Total obesity & 1.00 & $0.72(0.48-1.08)$ & $0.44(0.24-0.83)$ & $0.22(0.07-0.71)$ & $<0.001$ \\
\hline $\begin{array}{l}\text { Abdominal } \\
\text { obesity }\end{array}$ & 1.00 & $0.76(0.54-1.08)$ & $0.37(0.21-0.66)$ & $0.28(0.11-0.68)$ & $<0.001$ \\
\hline $\begin{array}{l}\text { Metabolic } \\
\text { syndrome }\end{array}$ & 1.00 & $0.91(0.54-1.53)$ & $0.22(0.07-0.64)$ & $0.24(0.05-1.02)$ & 0.001 \\
\hline $\begin{array}{l}\text { High caloric } \\
\text { intake }\end{array}$ & 1.00 & $0.89(0.68-1.15)$ & $0.58(0.40-0.85)$ & $0.71(0.45-1.13)$ & 0.008 \\
\hline $\begin{array}{l}\text { High fat } \\
\text { consumption }\end{array}$ & 1.00 & $1.01(0.95-1.08)$ & $1.02(0.95-1.10)$ & $0.97(0.87-1.08)$ & 0.875 \\
\hline Smoking & 1.00 & $0.77(0.52-1.14)$ & $0.76(0.47-1.23)$ & $1.23(0.74-2.05)$ & 0.817 \\
\hline Sedentarism & 1.00 & $0.92(0.80-1.05)$ & $0.88(0.74-1.05)$ & $0.47(0.32-0.68)$ & $<0.001$ \\
\hline
\end{tabular}


the associations presented here. In addition, some data about family income were missing (151 observations). In the statistical analysis, inverse probability of selection weighting was performed trying to mitigate selection bias.

The present results showed that low-income women had a worse cardiovascular profile than high-income women. Seven of the 15 cardiovascular risk factors investigated were more prevalent among low-income women, who also had a worse Framingham cardiovascular

Table 5. Association of cardiovascular risk factors with family income level in minimum wages among young adult men from Ribeirão Preto, in 2002-2004.

\begin{tabular}{|l|c|c|c|c|c|}
\hline \multicolumn{7}{|c|}{ Family income (minimum wages) } \\
$\begin{array}{l}\text { Cardiovascular } \\
\text { risk factors }\end{array}$ & $\begin{array}{c}<5 \\
(n=302)\end{array}$ & $\begin{array}{c}\geq 5 \text { and } \leq 9.9 \\
(n=288)\end{array}$ & $\begin{array}{c}\geq 10 \text { and } \leq 19.9 \\
(n=227)\end{array}$ & $\begin{array}{c}\geq 20 \\
(n=117)\end{array}$ & $\begin{array}{c}p \text {-value } \\
\text { for } \\
\text { trend }\end{array}$
\end{tabular}

Prevalence ratio (95\% confidence interval)

\begin{tabular}{|c|c|c|c|c|c|}
\hline High HOMA IR & 1.00 & $0.80(0.59-1.09)$ & $0.78(0.56-1.08)$ & $0.65(0.41-1.02)$ & 0.123 \\
\hline Diabetes & 1.00 & $0.98(0.23-4.01)$ & $0.84(0.15-4.60)$ & $1.33(0.24-7.28)$ & 0.882 \\
\hline $\begin{array}{l}\text { High LDL- } \\
\text { cholesterol }\end{array}$ & 1.00 & $1.20(0.61-2.33)$ & $1.24(0.62-2.49)$ & $2.23(1.11-4.48)$ & 0.054 \\
\hline $\begin{array}{l}\text { Low HDL- } \\
\text { cholesterol }\end{array}$ & 1.00 & $1.10(0.90-1.34)$ & $0.84(0.66-1.06)$ & $0.73(0.53-1.01)$ & 0.026 \\
\hline $\begin{array}{l}\text { High total } \\
\text { cholesterol }\end{array}$ & 1.00 & $1.54(0.71-3.33)$ & $0.96(0.38-2.39)$ & $1.27(0.43-3.75)$ & 0.845 \\
\hline $\begin{array}{l}\text { High } \\
\text { triglycerides }\end{array}$ & 1.00 & $0.90(0.60-1.34)$ & $1.34(0.92-1.95)$ & $0.82(0.47-1.41)$ & 0.692 \\
\hline High fibrinogen & 1.00 & $0.79(0.39-1.59)$ & $0.69(0.32-1.46)$ & $0.67(0.26-1.70)$ & 0.294 \\
\hline $\begin{array}{l}\text { High blood } \\
\text { pressure }\end{array}$ & 1.00 & $1.17(0.94-1.46)$ & $1.16(0.92-1.46)$ & $1.26(0.97-1.64)$ & 0.071 \\
\hline Total obesity & 1.00 & $0.95(0.64-1.41)$ & $0.68(0.42-1.10)$ & $0.57(0.29-1.12)$ & 0.130 \\
\hline $\begin{array}{l}\text { Abdominal } \\
\text { obesity }\end{array}$ & 1.00 & $0.89(0.57-1.39)$ & $0.72(0.43-1.20)$ & $0.64(0.32-1.28)$ & 0.120 \\
\hline $\begin{array}{l}\text { Metabolic } \\
\text { syndrome }\end{array}$ & 1.00 & $0.93(0.64-1.34)$ & $0.98(0.67-1.44)$ & $1.10(0.70-1.72)$ & 0.754 \\
\hline $\begin{array}{l}\text { High caloric } \\
\text { intake }\end{array}$ & 1.00 & $0.84(0.58-1.21)$ & $0.92(0.64-1.33)$ & $0.77(0.46-1.28)$ & 0.383 \\
\hline $\begin{array}{l}\text { High fat } \\
\text { consumption }\end{array}$ & 1.00 & $1.07(0.97-1.17)$ & $1.04(0.94-1.15)$ & $1.07(0.96-1.19)$ & 0.251 \\
\hline Smoking & 1.00 & $0.88(0.62-1.24)$ & $0.95(0.67-1.35)$ & $1.02(0.67-1.56)$ & 0.989 \\
\hline Sedentarism & 1.00 & $0.86(0.66-1.11)$ & $0.64(0.47-0.88)$ & $0.81(0.57-1.15)$ & 0.029 \\
\hline
\end{tabular}

HOMA IR: Homeostatic Model Assessment of Insulin Resistance; LDL: low-density lipoprotein; HDL: high-density lipoprotein. 
risk score. For men, only two of the 15 factors investigated were more prevalent among low-income subjects. In addition, there was no difference in the Framingham cardiovascular risk score among men.

Thus, it can be seen that the epidemiologic transition observed in Ribeirão Preto, a city in a middle-income country, occurred in a different manner according to sex: for women, the socioeconomic gradient of cardiovascular risk had already become inverted for almost the greatest part of the risk factors studied, suggesting that these women are already in the final phase of the epidemiologic transition. And for men, the socioeconomic gradient of cardiovascular risk became inverted only regarding two of the risk factors studied, suggesting that men are in the intermediate phase of the epidemiologic transition.

In this transition, the cardiovascular risk factors are first concentrated among high-income persons in high-income countries since these persons come in earlier contact with the "modern lifestyle". Later, some factors such as behavioral, nutritional and educational changes, access to health services and a greater practice of physical exercise lead to a reduction of these cardiovascular risk factors in the high-income population, and finally start to affect low-income persons by leading them to a worsening of their cardiovascular risk factors $\mathrm{s}^{7,8,21,22}$.

In middle-income countries, the process of epidemiologic transition started at a later time than in high-income countries. In addition, there is the fact that this transition may occur in a different manner at each location in middle-income countries, as observed in the present study in which the transition was faster and the association between income and worse cardiovascular risk was inverted only among women ${ }^{9,23}$. An Indian study on a population of an age similar to that of the present one detected a worsening of risk factors among their high-income subjects ${ }^{9}$, whereas a study conducted in the United States on a Hispanic population revealed that, despite the older age of the sample, high-income was associated with a reduction of risk factors ${ }^{24}$. The same has been found among elderly residents in São Paulo, Brazil, where low-income groups had higher CVD risk ${ }^{25}$.

The high-income women studied here showed a lower cardiovascular risk and completed the epidemiologic transition process before the men did. This fact may have been due to the greater concern of these women about consuming less caloric foods. Thus, their greater access to information and better financial conditions favor a healthy and balanced $\operatorname{diet}^{25}$. On the other hand, low-income women showed a higher caloric intake and were more sedentary, a fact that may have contributed to their higher prevalences of total obesity and abdominal obesity and of other cardiovascular risk factors ${ }^{26}$.

The greater practice of physical activity by high-income young adult women may be explained by their greater concern about having a "pleasant and healthy body". Thus, due to their greater health awareness, they adhere better to the practice of physical activity. This may have contributed to the fact that their BMI values are lower, with consequent lower prevalences of obesity and higher HDL-cholesterol ${ }^{27}$.

In agreement with another study, high-income women also showed lower prevalence of insulin resistance ${ }^{28}$. Although the prevalence of diabetes is low among young adults, the lower presence of insulin resistance favors lower odds of developing diabetes. The high-income 
women in the present study also showed lower prevalence of MS, which placed them in a situation similar to that encountered in higher income countries ${ }^{29}$.

Higher income women exhibited a better cardiovascular risk profile than men belonging to the same income class, a result in agreement with a study conducted in the United States $^{30}$. This may be explained by the fact that high-income women pay more attention to a healthy diet, to weight reduction and to physical activity, with their education possibly having positive effects of an economic and psychosocial order and protecting against adverse situations.

Kandasamy and Anand ${ }^{31}$ pointed out that, because of the genetic and hormonal characteristics and contraceptive use, women have higher risk of increased cardiovascular risk factors and cardiovascular diseases when compared to men. In addition to these risks, these authors affirm that being a woman and having low family income induce more problems and risks, often due to an array of social and structural circumstances, such as fragmented health care, social isolation, language difficulties, violence, caregiving burden, stress at home and early childhood adversity. Besides that, those with the lowest family income are least likely to access health services resources and treatments.

\section{CONCLUSION}

Low-income women had a worse cardiovascular risk than high-income women, in agreement with the epidemiologic transition that has occurred in high-income countries. In contrast, among men, there was no difference in cardiovascular risk according to family income, suggesting that men are still in the intermediate phase of the epidemiologic transition. Although the present sample consisted of a young population, the prevalence of some cardiovascular risk factors was already high.

\section{ACKNOWLEDGMENTS}

The authors wish to thank all the persons who participated in the planning of the research and in data collection and typing, as well as the subjects who accepted to participate in the investigation.

\section{REFERENCES}

1. Alwan A, Maclean DR, Riley LM, d'EspaignetET, Mathers $\mathrm{CD}$, Stevens GA, et al. Monitoring and surveillance of chronic noncommunicable diseases: progress and capacity in high-burden countries. Lancet 2010; 376(9755): 1861-8. https://doi.org/10.1016/S0140-6736(10)61853-3
2. Piepoli MS, Hoes AW, Agewall S, Albus C, Brotons C, Catapano AL, et al. European Guidelines on cardiovascular disease prevention in clinical practice. Eur Heart J 2016; 37(29): 2315-81. https:// doi. org/10.1093/ eurheartj/ehw106 
3. Albert MA, Glynn RJ, Buring J, Ridker PM. Impact of traditional and novel risk factors on the relationship between socioeconomic status and the incident cardiovascular events. Circulation 2006; 114(24): 2619-26. http:// doi.org/10.1161/ CIRCULATIONAHA.106.660043

4. Johnson-Lawrence M, Kaplan G, Galea S. Socioeconomic mobility in adulthood and cardiovascular disease mortality. Ann Epidemiol 2013; 23(4): 167-71. http: / / doi.org/10.1016/j.annepidem.2013.02.004

5. Mishra GD, Chiesa F, Goodman A, De Stavola B, Koupil I. Socio-economic position over the life course and all-cause, and circulatory disease mortality at age 50-87 years: results from the Swedish birth cohort. Eur J Epidemiol 2013; 28(2): 139-47. http:/ / doi.org/10.1007/s10654-013-9777-z

6. Stringhini S, Spencer B, Marques-Vidal P, Waeber G, Vollenweider P, PaccaudF, et al. Age and gender differences in the social patterning of cardiovascular risk factors in Switzerland: the CoLaus study. Plos One 2012; 7(11): e49443. http: / / doi.org/10.1371/journal.pone.0049443

7. Dong C, Rundek T, Wright CB, Anwar Z, Elkind MS, Sacco RL. Ideal cardiovascular health predicts lower risks of myocardial infarction, stroke, and vascular death across whites, blacks, and Hispanics: the northern Manhattan study. Circulation 2012; 125(24): 2975-84. http: / / doi. org/10.1161/CIRCULATIONAHA.111.081083

8. Popkin BM. The nutrition and obesity in the developing world. J Nutr 2001; 131(3): 871S-3S. https:// doi. org $/ 10.1093 / \mathrm{jn} / 131.3 .871 \mathrm{~S}$

9. Samuel P, Antonisamy B, Raghupathy P, Richard J, Fall C. Socio-economic status and cardiovascular risk factors in rural and urban áreas of Velorre, Talminadu. South India. Int J Epidemio 2012; 41(5): 1315-27. http: / / doi. org/10.1093/ije/dys001

10. Pisa P, Behanan R, Vorster H, Kruger A. Social drift of cardiovascular disease risk factors in Africans from the Noorth West Province of South Africa, the PURE study. Cardiovascular J Afr 2012; 23(7): 371-8. https: / / dx.doi.org/10.5830\%2FCVJA-2012-018

11. Popkin BM. The shift in stages of the nutrition transition in the developing world differs from past experiences. Public Health Nutr 2002; 5(1a): 205-14. http: / / doi.org/10.1079/PHN2001295

12. Wallace TM, Levy JC, Matthews DR. Use and abuse of HOMA modeling. Diabetes Care 2004; 27(6): 148795. http:// doi.org/10.2337/ diacare.27.6.1487

13. Hense HW, Koivisto AM, Kuulasmaa K, Zaborskis A, Kupsc W, Tuomilehto J. Assessment of blood pressure measurement quality in the baseline surveys of the WHO MONICA project. J Hum Hypertens 1995; 9(12): 935-46.

14. Ribeiro AB, Cardoso MA. Construção de um questionário de frequência alimentar como subsídio para programas de prevenção de doenças crônicas não transmissíveis. Rev Nutr 2002; 15(2): 239-45. http: / / dx.doi.org/10.1590/S1415-52732002000200012

15. Haskell WL, Lee IM, Pate RR, Powell KE, Blair SN, Franklin BA, et al. Physical activity and public health: update recommendations for the American College of Sports Medicine and the American Heart Association. Circulation 2007; 116(9): 1081-93. https:/ / doi.org/10.1161/CIRCULATIONAHA.107.185649

16. Yun K-J, Han K, Kim MK, Park Y-M, Baek K-H, Song K-H, et al. Insulin resistance distribuition and cut-off value in koreans from the 2008-2010 Korean National Health and Nutrition Examination Survey. Plos One 2016; 11(4): e0154593. http:/ / doi.org/10.1371/journal.pone.0154593

17. Institute of Medicine/Food and Nutrition Board. Dietary reference intake for energy, carbohydrate, fiber, fat, fatty acids, cholesterol, protein and aminoacids (macronutrients). Washington, D.C.: National Academy Press, 2002.p. 697-736.

18. Alberti KG, Eckel RH, Grundy MW, Zimmet PZ, Cleeman JI, Donato KA, et al. Harmonizing the metabolic syndrome: a joint interim statement of the International Diabetes Federation Task Force on Epidemiology and Prevention; National Heart, Lung, and Blood Institute; American Heart Association; World Heart Federation; International Atherosclerosis Society; and International Association for the Study of Obesity. Circulation 2009; 120(16): 1640-5. https: / / doi.org/10.1161/CIRCULATIONAHA.109.192644

19. D’Agostino, RB, Vasan RS, Pencina MJ, Wolf PA, Cobain M, Massaro JM, et al. General cardiovascular risk profile for use in primary care the Framingham Heart Study. Circulation 2008; 117(6): 743-53. http: / / doi.org/10.1161/ CIRCULATIONAHA.107.699579

20. Aitsi-Selmi A, Batty GD, Barbieri MA, Silva AAM, Cardoso VC, Goldani MZ, et al. Childhood socioeconomic position, adult socioeconomic position and social mobility in relation markers of adiposity in early adulthood: evidence of differential effects by gender in the 1978/79 Ribeirão Preto cohort study. Int J Obes 2012; 37: 439-47. http:/ / doi.org/10.1038/ ijo.2012.64

21. Lawlor DA, Harro M, Wadderkopp N, Andersen LB, Sardinha LB, Riddoch CJ, etal. Association of socioeconomic position with insulin resistance among children from Denmark, Estonia and Portugal: cross sectional study. BMJ 2005; 331(7510): 183. http:// doi.org/10.1136/ bmj.331.7510.183

22. Elovainio M, Ferrie JE, Singh-Manoux A, Shipley M, Batty GD, Head J, et al. Socioeconomic differences in cardiometabolic factors: social causation or health related selection? Evidence from the Whitehall II Cohort Study, 1991-2004. Am J Epidemiol 2011; 174(7); 779-89. http:/ / doi.org/10.1093/aje/kwr149 
23. Mayén AL, Marques-Vidal P. Paccaud F, Bovet P, Stringhini S. Socioeconomic determinants of dietary patterns in low and middle-income countries: a systematic review. Am J Clin Nutr 2014; 100(6): 152031. http: / doi.org/10.3945/ajcn.114.089029

24. Giardina EV, Paul TK, Hayes D, Sciacca RR. Cardiovascular disease risk among young urban women. J Women Health (Lamchmt) 2016; 25(11): 1139-46. https: / / doi.org/10.1089/jwh.2015.5697

25. Massa KHC, Pabayo R, Lebrão ML, Chiavegatto Filho ADP. Environmental factors and cardiovascular diseases: the association of income inequality and green spaces in elderly residents of São Paulo, Brazil. BMJ Open 2016; 6: e011850. http:// doi.org/10.1136/bmjopen-201601185

26. Lang SJ, Abel GA, Mant J, Mullis R. Impact of socioeconomic deprivation on screening for cardiovascular disease risk in a primary prevention population: a cross-sectional study. BMJ Open. 2016; 6: e009984. http:/ / doi.org/10.1136/bmjopen-2015-009984

27. Lindgren M, Börjesson M, Ekblom O, Bergström G, Lappas G, Rosengren A. Physical activity pattern, cardiorespiratory fitness, and socioeconomic status in the SCAPIS pilot trial-A cross sectional study. Prev Med Rep 2016; 4; 44-9. http://doi.org/10.1016/j.pmedr.2016.04.010

28. Tao X, Li J, Zhu X, Zhao B, Sun J, Ji L, et al. Association between socioeconomic status and metabolic control and diabetes complications: a cross-sectional nationwide study in Chinese adults with type 2 diabetes mellitus. Cardiovas Diabetol 2016; 15: 61. http: / / doi. org/10.1186/s12933-016-0376-7

29. Gannar F, de León CA, Díaz BB, Pérez MCR, Rodríguez IM, Dahmen FB, et al. Social class and metabolic syndrome in populations from Tunisia and Spain. Diabetol Meta Syndr. 2015; 7: 88. http:/ / doi. org/10.1186/s13098-015-0084-6
30. Winkleby MA, Kraemer HC, Ahn DK, Varady NA. Ethnic and socioeconomic differences in cardiovascular disease risk factors: findings for women from the Third National Health and Nutrition Examination Survey, 1988-1994. JAMA 1998; 280(4): 356-62. http:// doi. org/10.1001/jama.280.4.356

31. Kandasamy S, Anand SS. Cardiovascular disease among women from vulnerable populations: a review. Can J Cardiol 2018; 34(4): 450-7. http:// doi.org/10.1016/j. cjca.2018.01.017

Received on: 28/08/2018

Revised on: 15/12/2018

Accepted on: 26/01/2019

Authors' contribution: Fernando Alberto Costa Cardoso da Silva contributed to the interpretation of the data, to the drafting of the draft, to the critical review of content and participated in the approval of the final version of the manuscript. Maylla Luanna Barbosa Martins contributed to the analysis of the data, to the interpretation of the data, to the drafting of the draft, to the critical review of content and participated in the approval of the final version of the manuscript. Heloisa Bettiol and Viviane Cunha Cardoso and Marco Antonio Barbieri contributed to the design and planning, to the critical review of content and participated in the approval of the final version of the manuscript. Antônio Augusto Moura da Silva contributed to the design and planning, to the analysis of the data, to the interpretation of the data, to the drafting of the draft, to the critical review of content and participated in the approval of the final version of the manuscript. 